長崎県総合農林試験場東彼杵茶業支場*

宮田裕次・寺井清宗

(平成16年 5 月 27 日受理)

\title{
Effect of Application of Calcium Cyanamide on Raw Material Leaf Character and NDF Content of Crude Tea
}

\author{
Yuuzi Miyata and Kiyonori Terai \\ Nagasaki pref Agricultural and Forestry Experiment Station \\ Higashisonogi Tea Branch
}

\section{Summary}

The effect of application of calcium cyanamide to a tea garden on the NDF content of crude tea and the quality of tea manufacturing has been clarified. A reduced fertilizer application method using calcium cyanamide in spring makes the NDF content of crude tea of the first crop lower, and produces an equivalent or better quality of manufactured tea compared with a conventional fertilizer application method in the prefecture.

\section{1 緒 言}

近年，茶園への窒素肥料の過剩施肥が，環 境負荷として問題視されるようになった。こ のことから，農業技術研究機構，各府県の茶 関係研究機関は, 肥効調節型肥料 ${ }^{2}$, 被覆尿 素2), 石灰窒素等†゙を用いた隇肥試験に取り組 み, 窒素施肥量を削減しても生葉収量や品質 が劣らないことを明らかにした。その成果に
る† ${ }^{2}$ 特に, 石灰窒素は, 硝化抑制効果があり 土壤中にアンモニア態窒素を長く残存させ, 土壤中からの硝酸態窒素の溶脱が軽隇できる 等の報告がされている ${ }^{3-5)}$ 。そこで, 本県の年 間窒素施肥基準量に対して石死窒素, 肥効調 節型肥料を用いて隇肥試験を行ったところ， 石灰窒素の施用が一番茶の原葉形質及び荒茶 中の中性デタージェント緎維 (NDF) 含有率 に及沽す影響について新しい知見を得たので 報告する。

より，全国的に窒素施肥量が削減傾向にあ

* $\overline{\mathrm{T}} 859-3801$ 長崎県東波杵郡東彼杵町中尾郷1414

$\dagger^{1}$ 野菜・茶業試験研究推進会議 野菜・茶業試験場: 平成11年度野菜・茶業研究成果 情報, pp.2526 (2000).

$\dagger^{2}$ 独立行政法人 農業技術研究機構 野菜茶業研究所：平成14年度課題別研究会資料，pp.55-59 (2002). 


\section{2 実 験 方 法}

\section{1 材料および方法}

試験地の長崎県総合農林試験場東彼杵茶業 支場は，標高 $380 \mathrm{~m} ，$ 年平均気温 $14.6^{\circ} \mathrm{C}$, 年間 降水量約 $2,400 \mathrm{~mm}$, 土堷は玄武岩を母材とす る細粒質黄色土である。試験区と処理法は， 表 1 に示すとおり石扊窒素と肥効調節型肥料, 硫安を組み合わせた石灰窒素区, 肥効調節型 肥料と硫安を用いた肥効調節型肥料区，有機 入化成肥料と硫安を用いた有機入化成肥料区 （慣行区）を設け，慣行区は年間窒紊施用量 を10a当たり $60 \mathrm{~kg}$, 肥効調節型肥料区と石扊素 区は $45 \mathrm{~kg}$ とした。各試験区は 1 区 $108 \mathrm{~m}^{2}$ の 2 反 復で行った。供試茶葉は当支場内で栽培した ‘やぶきた’2001（26年生）～2002年（27年生） に黒色カンレイシャ（遮光率60\%）で被覆栽 培した一番茶，二番茶を用いた。摘採した生 葉は, 各試験区 $60 \mathrm{~kg}$ に分け, 直ちに60k型製茶 機で製造した。

\section{2 調查項目お沃び試験方法}

原葉形質，として出開度，百芽重，摘芽長， 摘芽の葉数を調查した。出開度は，摘採時に 摘採新梢 200 本の心の止まった新梢の割合で示 した。百芽重は，摘採新梢200本の重量を測定 し，新梢 100 本の重量に換算した。摘芽長は， 摘採新梢 40 本の茥長を測定し, 平均値で示し た。摘芽の葉数は，摘採新梢 40 本の葉数の平
均値で示した。荒茶中のNDF含有率は近赤外 線分光光度計 (DICKEY-john社製, GT-8S) を用いて測定した。官能審査は, 形状, 色沢, 香気, 水色, 滋味を各20点満点とする標準審 查法で行った。

\section{3 結果及び考察}

一番茶の原葉形質については，2001年では 石灭窒素区の出開度が他の試験区に比べ進ん でいた。また，石灰窒素区の摘芽長が肥効調 節型肥料区に比べ $1 \mathrm{~cm}$ 長かったにも関わらず, 荒茶中のNDF含有率は, 石灰窒素区が最も低 かった。2002年では， 3 試験区とも出開度に ついては同程度であったが, 荒茶中のNDF含 有率は，2001年と同じく石灰窒素区が低かつ た（表 2 )。製茶品質の内質は 2 カ年とも石灰 窒素区と慣行区が優れ，外観は 2 力年とも石 灰窒素区が優れた(表 3 )。石灰空素区の外観 が優れたことは, 荒茶中のNDF含有率が低い ことによると考えられる。二番茶荒茶中のNDF 含有率は2002年の有機入化成肥料区でやや低 く, 出開度も低かった。一方，石灰窒素区及 び肥効調節型肥料区では2001年，2002年の 2 カ年とも荒茶中のNDF含有率には差は見られ なかった（表 2)。また，製茶品質は一定の傾 向が見られなかった（表 3 )。

一般に，出開度が進むにつれて茎や下葉が 硬化し，全窒素含有率や遊離アミノ酸含有率 が低下し，製茶品質が低下することが明らか

表 1 試験区と処理方法

\begin{tabular}{|c|c|c|c|c|c|c|c|c|}
\hline 試験区名 & $(\mathrm{kgN} / 10 \mathrm{a})$ & 2月上旬 & $\begin{array}{c}\text { 春 肥 } \\
2 \text { 月下旬 }\end{array}$ & $\begin{array}{r}\text { 芽出し肥 } \\
4 \text { 月上旬 }\end{array}$ & $\begin{array}{c}\text { 追肥 I } \\
5 \text { 月中旬 }\end{array}$ & $\begin{array}{l}\text { 追肥 II } \\
6 \text { 月下旬 }\end{array}$ & $\begin{array}{c}\text { 秋 肥 } \\
8 \text { 月下旬 }\end{array}$ & $\begin{array}{c}\text { 堆 肥 } \\
\text { 11月 }\end{array}$ \\
\hline 石灰窒素区 & $45 \mathrm{~kg}$ & $\begin{array}{c}\text { 石灰窒素 } \\
(15.0)\end{array}$ & 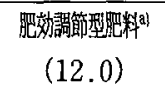 & $\begin{array}{l}\text { 硫安b) } \\
(3.0)\end{array}$ & & & $\begin{array}{c}\text { 肥効䍖節型肥料 } \\
(15.0)\end{array}$ & $(1.5 \mathrm{t})$ \\
\hline 肥效調節型肥料区 & $45 \mathrm{~kg}$ & & $\begin{array}{c}\text { 肥效調節型肥料 } \\
(18.0)\end{array}$ & $\begin{array}{l}\text { 硫安 } \\
(4.5)\end{array}$ & & & $\begin{array}{c}\text { 肥饺調節型肥料 } \\
(22.5)\end{array}$ & $(1.5 \mathrm{t})$ \\
\hline $\begin{array}{c}\text { 有㭗入化成肥料区 } \\
(\text { 慣行区) }\end{array}$ & $60 \mathrm{~kg}$ & & $\begin{array}{c}\text { 有機入化成肥料 } \\
(18.0) \\
(18.0)\end{array}$ & $\begin{array}{l}\text { 硫安 } \\
(6.0)\end{array}$ & $\begin{array}{l}\text { 硫安 } \\
(9.0)\end{array}$ & $\begin{array}{l}\text { 硫安 } \\
(9.0)\end{array}$ & $\begin{array}{c}\text { 有機入化成肥料 } \\
(18.0)\end{array}$ & $(1.5 \mathrm{t})$ \\
\hline
\end{tabular}

a ) $\mathrm{N}: \mathrm{P}: \mathrm{K}=14: 8: 8,100$ 日タイプ（臸素成分 $3 \% ） と 70$ 日タイプ（窒素成分 $4 \%$ ）の混用，リニア型

b) $\mathrm{N}: \mathrm{P}: \mathrm{K}=21: 0: 0$

c) $\mathrm{N}: \mathrm{P}: \mathrm{K}=10: 8: 8$, 有機質 $50 \%$ 配合

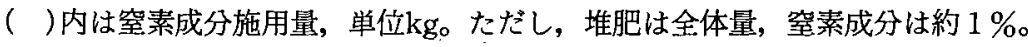


になっている,7)。しかし，本試験では，石灰 窒素区に打ける一番茶の出開度が, 他の試験 区に比べ進んでいるか同程度であるが，荒茶 中のNDF含有率が低く，製茶品質も優れる結 果となった。また，NDF含有率は葉に比べ菱 の方に高いことも知られている7)。かし，本 試験では，石死窒素区の茥が長くても一番茶 荒茶中のNDF含有率が低い結果となった。今 回の試験は石灰窒素区が春肥重点で，2 月上 旬に石灭窒素, 2 月下旬に肥効調節型肥料を
施用したことで石灰窒素による硝化抑制効果 から，土壌中に無機態窒素が長く残存でき， 一番茶荒茶中のNDF含有率が低下したと考え られる。このことは，窒素施用量が少なくな るにつれてNDF含有率が高くなる傾向が認め られる ${ }^{8}$ 報告があり,このことに関係するもの と思われる。

以上の結果から, 石灰窒素の利用により， 一番茶荒茶中のNDF含有率が低下し, 品質は 向上し, 施肥の削減も図れると考えられる。

表 2 一、二番茶の原葉形質と荒茶成分

\begin{tabular}{|c|c|c|c|c|c|}
\hline & \multirow[b]{2}{*}{ 試 験 区 } & \multicolumn{3}{|c|}{ 原葉形質 } & \multirow{2}{*}{$\begin{array}{c}\text { 荒茶成分 } \\
\text { NDF } \\
(\%)^{a)}\end{array}$} \\
\hline & & $\begin{array}{c}\text { 出開度 } \\
(\%)\end{array}$ & $\begin{array}{c}\text { 百芽重 } \\
(\mathrm{g})\end{array}$ & $\begin{array}{c}\text { 摘芽長 } \\
(\mathrm{cm})\end{array}$ & \\
\hline \multirow[t]{3}{*}{ 2001年一番茶 } & 石灰窒素区 & 58.5 & 50.8 & 5.0 & 16.8 \\
\hline & 肥効調節型肥料区 & 48.8 & 46.6 & 3.9 & 17.6 \\
\hline & 有機入化成肥料区 & 51.0 & 43.9 & 4.4 & 18.0 \\
\hline \multirow[t]{3}{*}{ 2001年二番茶 } & 石灰窒素区 & 54.0 & 34.7 & 3.5 & 19.3 \\
\hline & 肥効調節型肥料区 & 49.1 & 42.9 & 3.7 & 19.9 \\
\hline & 有機入化成肥料区 & 53.6 & 40.6 & 4.0 & 19.6 \\
\hline \multirow[t]{3}{*}{ 2002年一䆏茶 } & 石灰窒素区 & 72.8 & 67.5 & 4.9 & 18.3 \\
\hline & 肥効調節型肥料区 & 69.5 & 67.5 & 5.3 & 19.3 \\
\hline & 有機入化成肥料区 & 72.7 & 62.2 & 4.9 & 18.6 \\
\hline \multirow[t]{3}{*}{ 2002年二番茶 } & 石灰窒素区 & 64.1 & 44.3 & 2.4 & 19.1 \\
\hline & 肥効調節型肥料区 & 56.1 & 33.8 & 3.1 & 19.3 \\
\hline & 有機入化成肥料区 & 37.1 & 36.1 & 3.4 & 18.4 \\
\hline
\end{tabular}

a ) 乾物\%

表 3 肥料の種類と製茶品質

\begin{tabular}{|c|c|c|c|c|c|c|c|c|c|}
\hline & \multirow[b]{2}{*}{ 試 験 区 } & \multicolumn{2}{|c|}{ 外 } & 観 & \multicolumn{2}{|c|}{ 内 } & \multicolumn{2}{|c|}{ 質 } & \multirow[b]{2}{*}{ 合計 } \\
\hline & & 形状 & 色沢 & 小計 & 香気 & 水色 & 滋味 & 小計 & \\
\hline \multirow[t]{3}{*}{ 2001年一番茶 } & 石灰窒素区 & 13.5 & 13.5 & 27.0 & 13.0 & 13.0 & 12.5 & 38.5 & 65.5 \\
\hline & 肥効調節型肥料区 & 13.5 & 13.0 & 26.5 & 13.0 & 12.5 & 12.5 & 38.0 & 64.5 \\
\hline & 有機入化成肥料区 & 12.0 & 13.0 & 25.0 & 12.5 & 13.0 & 13.0 & 38.5 & 63.5 \\
\hline \multirow[t]{3}{*}{ 2001年二番茶 } & 石灰窒素区 & 11.5 & 11.0 & 22.5 & 10.5 & 11.0 & 11.5 & 33.0 & 55.5 \\
\hline & 肥効調節型肥料区 & 11.5 & 11.5 & 23.0 & 10.5 & 11.5 & 12.0 & 34.0 & 57.0 \\
\hline & 有機入化成肥料区 & 11.0 & 11.0 & 22.0 & 11.5 & 11.0 & 10.5 & 33.0 & 55.0 \\
\hline \multirow[t]{3}{*}{ 2002年一番茶 } & 石灰窒素区 & 14.5 & 15.0 & 29.5 & 12.5 & 13.5 & 12.5 & 38.5 & 68.0 \\
\hline & 肥効調節型肥料区 & 13.5 & 14.5 & 28.0 & 12.0 & 13.0 & 12.0 & 37.0 & 65.0 \\
\hline & 有機入化成肥料区 & 14.5 & 15.0 & 29.5 & 13.0 & 13.5 & 12.5 & 39.0 & 68.5 \\
\hline \multirow[t]{3}{*}{ 2002年二番茶 } & 石灰窒素区 & 11.5 & 11.5 & 23.0 & 9.0 & 12.0 & 10.0 & 31.0 & 54.0 \\
\hline & 肥効調節型肥料区 & 12.0 & 11.5 & 23.5 & 9.0 & 13.0 & 10.0 & 32.0 & 55.5 \\
\hline & 有機入化成肥料区 & 11.5 & 11.5 & 23.0 & 9.5 & 12.0 & 10.5 & 32.0 & 55.0 \\
\hline
\end{tabular}




\section{4 摘 要}

石灰窒素の茶園への施用が荒茶中のNDF含 有率及び製茶品質に及ぼす影響を明らかにし た。石灰空素を春施用した省肥施肥法は，県 慣行施肥法に比べて,一番茶荒茶中のNDF含 有率が低くなり，製茶品質も同等以上となっ た。

\section{5 引用文献}

1) 喜多嶋秀之・松ヶ谷祐二・磯部宏治・出 岡裕哉 (2002)：窒素40kgレベルでの少肥 栽培現地実証事例, 茶研報No.94(別), 82-83.

2 ) 徳田進一 - 石井聡 - 内野聖久 - 㻕江正晃 加藤忠司 (1999)：被覆尿素を使った窒素 施肥量 - 施肥回数削減試験, 茶研報 No.88(別), 74-75.

3 ) 西野恒夫 (1993)：茶園土垬に打ける硝酸
化成抑制肥料及び硝酸化成抑制剤の効果 における試験, 茶研報No.78(別), 52-53.

4 ) 西野恒夫(1995)：茶園におりる硝化抑制 阂の効果, 茶研報No.82(別), 112-113.

5) 加藤忠司 - 山口泰明 - 溝口健作 (1996)： 石灰窒素及びジシアンジアミド施用茶園 における無機態窒素の動態, 茶研報 No.84 (別), 134-135.

6 ）高柳博次・阿南豊正・池ヶ谷賢次朗・中 川致之 (1985)：茶芽の熟度と成分変動, 茶研報No.61，20-25.

7 ）㴊之上康元 - 刹之上弘子 (1999)：栽培・ 製茶法と茶の成分・品質, 日本茶全書, 農文協，pp.213-215.

8 ) 阿南豊正 (2003) : 窒素施用量の違いがや ぶきた，さやまかおり，かなやみどり， めいりょく’新芽中の化学成分含有率に 及涩す影響, 茶研報No.96, 33-47。 